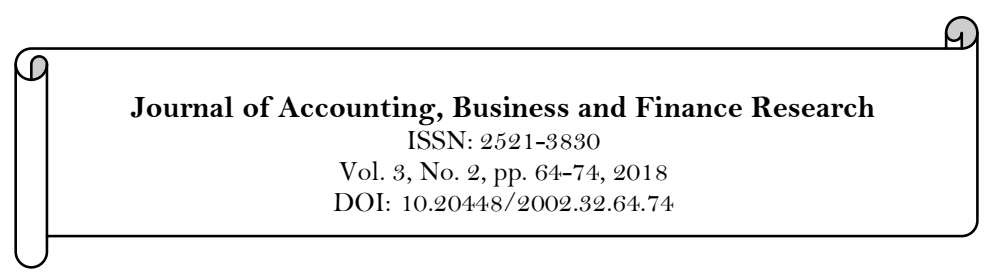

\title{
Social Network and Family Business Internationalization in South Eastern Nigeria
}

\author{
Kenneth Chukwujioke Agbim ${ }^{1 *}$ \\ Johnny Eluka ${ }^{2}$ \\ ${ }^{1}$ Business Administration Department, University of Agriculture, Makurdi, Nigeria. \\ Email: kennethagbim2012@gmail.com \\ ${ }^{2}$ Department of Management, University of Nigeria, Enugu Campus, Enugu, Nigeria.
}

\begin{tabular}{|c|c|}
\hline Abstract & \\
\hline $\begin{array}{l}\text { Social network relationships through social associations, clubs and } \\
\text { social networking platforms are known to facilitate family business } \\
\text { internationalization. However, this has not been empirically brought } \\
\text { to the fore with respect to the family businesses in Nigeria. Owing to } \\
\text { the commonplaceness of social networks and family businesses in } \\
\text { South Eastern Nigeria and their involvement in cross border } \\
\text { business, this study seeks to examine the effect of social network on } \\
\text { the internationalization of family businesses in the zone. The study } \\
\text { adopted survey design. Proportionate stratified random sampling } \\
\text { and simple random sampling techniques were employed to determine } \\
\text { the sample size. The generated data via questionnaire were analyzed } \\
\text { using linear regression. The results show that the effect of social } \\
\text { network on family business internationalization is significant and } \\
\text { positive. The study therefore lends itself as a veritable empirical } \\
\text { evidence and support to the Uppsala Internationalization Process } \\
\text { Model. To promote cross border business, the researchers } \\
\text { recommends the sensitization of family business founder/CEOs or } \\
\text { descendant/CEOs on the need to belong to both national and } \\
\text { international social associations. This social relationship has the } \\
\text { potential of: fostering in founder/CEOs the use of social network } \\
\text { platforms for communication; exposing the founder/CEOs to } \\
\text { international business knowledge/experience; and linking } \\
\text { founder/CEOs to foreign partners, investors, funds, facilities and } \\
\text { markets. }\end{array}$ & $\begin{array}{l}\text { Licensed: } \\
\text { This work is licensed under a } \\
\text { Creative Commons Attribution } \\
\text { 4.0 License. } \\
\text { Publisher: } \\
\text { Scientific Publishing Institute }\end{array}$ \\
\hline
\end{tabular}

\section{Introduction}

Social network refers to the relationships among friends in a social club, social association or through social networking platform for mutual interest. These relationships facilitate resource sharing and exchange among participating actors. One area where these resources have been brought to bear is business, particularly family business internationalization. Family business internationalization is the process of learning and accumulating knowledge on international business in preparation to getting involved in export, investment in a foreign business, starting a foreign subsidiary or inclusion of expatriates in the top management of a family business.

The establishment of networks has been generally considered essential in family business development (Hamid, 2013). This view has been explained by the Uppsala Internationalization Process Model developed by Johansson and Vahlne (1977). This Model is based on Johansson and Wiedersheim-Paul's "establishment chain" or "step by step" theoretical framework. The model focus on the state and change aspects that firms go through when going abroad. State aspects are the resources committed to the foreign market: market knowledge and commitment decision that would affect the firm's opportunities and risks. Change aspects on the other hand are the results of the state aspects: market commitment and current activities (Masum \& Fernandez, 2008). The Model proposes that firms incrementally internationalize their operations along an establishment chain and a psychic distance chain. This implies that increased knowledge (through experience) leads stepwise to higher commitment entry modes in psychologically more distant countries (Pukall \& Calabro, 2014). 
Incremental growth suggests that companies begin internationalization process in markets that have less psychic distance. Psychic distance is defined as factors such as differences in language, culture and political systems which disturb the flow of information between the firm and the market (Masum \& Fernandez, 2008). Owing to the criticism of the Uppsala Internationalization Process Model, Johansson and Vahlne 32 years after revisited their Model. The main addition to the new Model is that networks and network relationships are the main drivers of firm internationalization (Johanssons \& Vahlne, 2009). Johansson and Vahlne note that "insidership" in networks is crucial for the internationalization process. The new Uppsala Model assumes that a firm's intention to venture abroad may be triggered and facilitated by the contacts in its existing networks (Johanssons \& Vahlne, 2009; Pukall \& Calabro, 2014).

The network approach to the study of entrepreneurship which was introduced by Aldrich and Zimmer in 1986 emphasize that although entrepreneurs may possess some ideas and skills, they further need resources from their external environment to enable them start-up and continue to pursue the development of their businesses. Entrepreneurs access resources through network (Abou-Moghli \& Al Muala, 2012). In Nigeria, social networks and international businesses are commonplace. However, the contribution of social network to family business internationalization has not been empirically established. Essentially, in South Eastern Nigeria, it is difficult to state when business as an occupation started. Anagbogu assert that it is believed to have started in the early period. The artefacts from Igboukwu archaeological investigation prove the involvement of Igboland in international business. Igboland through the Sahara exported ivory, slaves and palm oil/kernels, and imported among others such things as iron/copper objects, cloths and glass beads (Anagbogu, 2008).

Today, many of the family business founder/CEOs in Nigeria engage less in cross border business owing to the high exchange rates, lack of knowledge/experience in international business and unfavourable international business environment. In addition, the few founder/CEOs who have internationalized their businesses only engage more in importation than exportation. For instance, Chief Eric Umeofia, the founder/CEO of Erisco Foods relocated his company to China after losing $¥ 3.5$ billion in Nigeria. Also, the owner of Kotec Group, Chief Emenike Chika abandoned his machineries, hardware and spare parts business for the production of noodles owing to competition from similar products from China. Consequently, this study seeks to examine the effect of social network on family business internalization in South Eastern Nigeria.

\section{Literature Review \\ 2.1. Family Business}

The term "family" refers to a group of people related to each other by blood or marriage (Belenzon, Patacconi, \& Zarutskie, 2015). Today, families are establishing family businesses to create opportunities for their children, perpetuate family inheritance, hold the family together, give the families financial independence and inheritance (Ayranci, 2010). Family business is an emerging aspect of entrepreneurship (Ramona, Hoy, Poutziouris, \& Steier, 2008) that is made up of the family (nuclear and extended) and business systems (Gersick, Davis, McCollom, Hampton, \& Lansberg, 2007). The family system is internally oriented. Thus, it focuses more on family and social agenda. This includes maintaining balance within the family by minimizing or repressing family conflict (Westhead, Wright, \& McElwee, 2011). The business system focuses more on business agenda such as tasks achievement. Among other things, these tasks include production of goods and services to make profit. Owing to its external oriented nature, business system changes to maintain balance in the environment (Warnar, 2012).

Zahra, Hayton, and Salvato (2012) define family business as those businesses that report some identifiable share of ownership by at least one family member and having multiple generations in leadership positions within that firm. Combining several variables, Poza (2014) define family business as a unique synthesis of: firstly, ownership control by two or more family members; secondly, managerial influence through active participation, advisory role, board membership or active shareholding; thirdly, concerns for family relationships; and finally, the possibility of continuity across generations.

\subsection{Social Network}

Social network is referred to as a set of linkages among individuals who are bonded by the set of ties formed amongst them (Aldrich \& Zimmer, 1986). There is generally a growing belief that social network facilitates business stakeholder engagement activities. This is evident in its increasing use by business owners (Palanissamy, 2014). Thus, Fombrun (1982) view social network as the inter-relationship between the entrepreneurs (ego) and their contacts [alter(s)] for business purposes. Alter(s) comprise family members, friends, relatives, business contacts, social associations and clubs (Chuairuang, 2013). Moreover, today, social network is being used to search for information, knowledge, friendship, social support (Harris \& Rae, 2009), and for marketing, collaboration, education and entertainment (Kaplan \& Haenlein, 2010). The actors in a social network can be roles, individuals or organizations (Johannission, Ramirez-Pasilas, \& Karlson, 2002). Social network is used by firms to improve their performance and to maintain their effectiveness in the market (Batiz-Lazo \& Woldesenbet, 2006). 
Business-owner managers employ social networking platforms like Facebook, YouTube, Instagram, Linkedln, Twitter, Skype and Wordpress to enhance their relationship in the social network. Social network allow owner-managers that are positioned in the social web to be the first to obtain information on potential business opportunities (Coutinho \& Moutinho, 2012). The owner-managers also obtain resources with which to successfully compete with large firms and to contribute to the growth of their businesses (Lechner, Dowling, \& Welpe, 2006).

Social network can be described along three network dimensions: structural (e.g., who is near whom); relational (e.g., how strong are bonds between actors); and cognitive (e.g., how similar are the minds in the network). These dimensions are used as proxies of social network (Neergaard, 2005; Sheriff, 2012). The ties in a social network can be strong or weak. Strong ties include relationship an entrepreneur has with family members, close relatives and good friends. They are based on frequent contacts and emotional closeness. Strong ties are relationships that an entrepreneur can "count on". Strong ties enhance exchange and long-term relationships, and promotes the development of trust and the transfer of information and tacit knowledge (Anderson, Jack, \& Dodd, 2005; Granovetter, 1983). They also exist among nascent entrepreneurs (Aldrichh \& Martinez, 2001).

Weak ties on the other hand are long-term relationships that focus on goal fulfilment for both parties (Smelser \& Baltes, 2001). Weak ties exist among individuals with infrequent and generally non-affective contacts. Weak ties include relationships an entrepreneur has with suppliers, customers, new business friends, government agencies and chambers of commerce. Granovetter (1983) view weak ties as channel for opportunity discovery and to access a wide variety of resources. Elfring and Hulsink (2003) opine that social networking can be made effective by blending strong and weak ties. This is because weak ties make available information that may not be readily provided by strong ties (Granovetter, 1973). Strong and weak ties complement each other in different roles, for different purpose or in different populations. Chell and Baines (2000) assert that weak and strong ties contribute to business development. Therefore, the strength of the tie between an entrepreneur and a network participant can be positioned along a continuum from "weak" to "strong” (Kozan \& Akdeniz, 2014; Surin \& Wahab, 2013).

\subsection{Family Business Internationalization}

Internationalization is the extent to which firms get involved in cross border business. It is based on the capability of a firm to exploit its local advantages within foreign markets (Gulsoy, Ozkanly, \& Lynch, 2013; Mazzola, Machisio, \& Astrachan, 2008). Internationalization is also defined as the process of learning and accumulating international knowledge and experience. International knowledge is knowledge in foreign ventures, foreign markets, information, multinational culture and the buyer behaviour in foreign market. International experience is referred to as the dealings with foreign business partners and the formation of cooperative agreements with foreign agents (Chelliah, Pandian, Sulaiman, \& Munusamy, 2010).

International knowledge and experience can be obtained by employing professionals with appropriate education and experience and from their networks. Thus, family businesses achieve internationalization faster when working in collaboration with others. This collaboration could take the form of exploitation of goods/services, shareholding by foreigners, inclusion of foreigners in the top management board and establishment of foreign subsidiaries (Chelliah et al., 2010; da Silva \& de Macedo-Soares, 2013; Pukall \& Calabro, 2014). Most firms start small and gradually internationalize, while others start as international firms. However, small firms have stronger tendency to internationalize than large firms. This is because small firms are looking for broader markets for their products/services (Chelliah et al., 2010). Thus, internationalization is a strategic entrepreneurial behaviour for achieving business development. But, Basly (2007) argue that family businesses internationalize after developing in their home country.

The family characteristics that influence internationalization include: (i) strength of leadership shown by the family - active involvement of family members in the management of the business, shareholding by family members who are not actively involved in the management of the business, influence of the previous generation on the current generation, and the involvement of agents in the management of the business; (ii) degree of international orientation - although small at start-up but the founder has a picture of a large business in mind. The degree of international orientation is the extent to which the family members believe that the natural geographical scope of the business should be limited within or beyond the borders of the country of origin (Segaro, 2012). International orientation affects the family members' perceptions of the nature of the international business environment, levels of risks involved and the diversities in cultures; (iii) the commitment, long-term orientation and unique capabilities of family members. This mind set among other things help the family members to identify and exploit international opportunities as a long-term survival strategy (Cerrato \& Piva, 2012; Huang, Lo, Liu, \& Tung, 2014); and (iv) the education and experience of the next generation makes them better prepared to assume international responsibilities (Bjornberg \& Nicholson, 2012; Mazzola et al., 2008).

Internationalization is affected by pull and push factors. Push factors are the pressures, while the pull factors are the opportunities for family businesses considering internationalization. The push factors that influence family businesses to expand beyond their domestic national markets are strategic drivers, 
competitive forces and family demands. Strategic drivers include access to crucial resources at low costs, identification and deployment of new products through synergies with offshore partners and matching supply chain requirement. Competitive forces include developing presence in overseas markets to pre-empt competition, taking defensive move against offshore competition and making use of global supply chain for cost-effective sourcing in relation to competition (Mazzola et al., 2008). In internationalization, family demands include financial needs, need to offer employment opportunities and the need to offer educational opportunities to the next generation (Bjornberg \& Nicholson, 2012; Mazzola et al., 2008; Welsh, Memili, Rosplock, Roure, \& Segurado, 2013).

The pull factors for family businesses to venture into international markets include desirable location, alliances, incentives, networks and pre-emptive positions (Machisio, Mazzola, Sciascia, Miles, \& Astrachan, 2010; Schjoedt, Monsen, Pearson, Barnett, \& Chrisman, 2012). Desirable locations are of two types - business and family levels. The business level desirable locations enable family businesses to gain key business positions and dominance in products/services. The family level desirable locations are the attractive places where family members prefer to live or travel to. Network alliances give family businesses access to international market. The incentives are the inherent benefits in business opportunities. The pre-emptive positions are the advantages that accrue to first movers in a market place which motivate family businesses to expand internationally (Patel, Pieper, \& Hair, 2012).

Expansion into international markets can be hampered by lack of strategic resources, uncertainty, complexity of the process and lack of information on foreign market (Gulsoy et al., 2013; Mazzola et al., 2008). Other challenges of internationalization are its costs. These include unfamiliarity with the environment and culture, political and economic differences, coordination difficulties, incentive misalignment and inadequate substantial investment facilities (Chen, 2011). Despite these challenges, internationalization still offer access to new resources, institutions and foreign stakeholders which increase the potential of generating high returns to family firms that have the unique resources (Holt, 2012; Lin, 2012; Machisio et al., 2010). Furthermore, internationalization is beneficial to family businesses in many ways. These include: economies of scale and scope; availability of domestic products/services in the international markets; enhancing revenue through increasing market power; and decreasing revenue fluctuations through spreading investment risks in different countries (Murray \& Robert, 2013; Shane, Marilyn, \& Rumintha, 2012; Tsao \& Lien, 2013).

\subsection{Theoretical Framework}

The resource dependence theory, agency theory and resource-based view are reviewed to form the theoretical underpin for this study.

\subsection{Resource Dependence Theory}

Resource dependence theory was propounded by Salancik and Pfeffer (1978). The theory states that firms create interdependent relationships with their external environment owing to the uncertainties from their uncoordinated social units and external environment. Subsequently, these interdependent relationships are transformed into linkages for the purpose of acquiring and sharing resources with which to improve their effectiveness, performance and outcome (Pfeffer \& Salancik, 1978; Sengenberger \& Pyke, 1992). Family businesses depend on resources such as finance, knowledge and advice which are only available outside their formal boundaries (Naldi \& Nordqvist, 2008). They are linked to these resources through networks (Chuairuang, 2013). These interdependent relationships can be managed through: (1) the acquisition of control over critical resources that firms' need thereby reducing the focal firms dependence on others; or (2) the acquisition of control over critical resources that others need, thus increasing others dependence on the focal firm through agency relationships. Therefore, agency theory complements resource dependence theory (Chuairuang, 2013).

\subsection{Agency Theory}

The agency theory as propounded by Jensen and Meckling (1976) holds that a business enterprise has a set of agency relationships among its numerous stakeholders. The stakeholders include business owners, managers, customers, suppliers, creditors, employees and the community. These relationships involve agency costs, which arise when the agent and the principal have separate goals and ambitions (Barrett, 2014; Chuairuang, 2013; Jensen \& Meckling, 1976). The agency costs also exist because of the transaction costs involved in resolving the conflict of interest between owner-managers and capital providers. The relative transaction costs will vary depending on the amount being borrowed. The agency problems that may arise from the relationships are resolved when the capital providers use various types of protective covenants and monitoring devices to monitor the behaviour of the agents so as to protect themselves (i.e., the principals). The resource-based view adds to agency theory by reducing or eliminating the agency costs that are normally present when the property and administration of a business are in the hands of people who are not related by kinship (Chuairuang, 2013).

The general management literature has seen the more recent development of multiple agency perspective (Arthurs, Hoskisson, Busenitz, \& Johnson, 2008) that moves beyond a simplistic principal-agent dichotomy 
and considers multiple governance roles of the same participants in the firm's governance mechanism. Development of multiple agency theory research have begun to recognize that it is not a universal theory that applies in the same way in different institutional settings, but rather its applicability depends upon the context (Brutton, Filatotchev, Chahine, \& Wright, 2010). In the small family firm environment where owners and managers are one and the same, conflict in such firm is between the small firms and their capital providers. In quoted family businesses, the task of furnishing adequate incentives and monitoring falls first to the board of directors (Chuairuang, 2013).

\subsection{Resource-Based View}

The resource-based view was first theorized by Wernerfelt (1984). The resource-based view holds that firms are bundles of productive resources with different bundles of these resources being either very costly to copy or inelastic in supply (Barney, 1991; Ferreira, Azevedo, \& Ortiz, 2011; Wernerfelt, 1984). Resource-based is define as the resources and capabilities possessed by competing firms that may be long lasting, while a firm's resources are those tangible and intangible assets that are tied semi-permanently to the firm (Barney, 1991; Ichraikie, 2013).

No business enterprise has all the resources it requires. Thus, business enterprises need to either obtain the "bought" or "support" resources they need from other entrepreneurs or business enterprises in their business environment. In family business research, the resource-based view has been employed to associate certain features that enhance performance/development in family business to the resources and capabilities displayed by family businesses. The features are family members' commitment and dedication, and customers trust and perception. The resources and capabilities are human capital, social capital, patient capital, survivability capital, governance structure and networks. According to the resource-based view, the capabilities of a firm confer upon it the resources to develop (Chuairuang, 2013; Duran-Encalada, MartinReyna, \& Montiel-Campos, 2012).

\subsection{Effect of Social Network on Family Business Internationalization}

Bello (2009) conducted a study to identify the strategies developed by Cameroonian SMEs to ensure their success abroad and the factors that explain the choice of these strategies. The study adopted survey design. Questionnaire technique was employed to generate the study data from 41 Cameroonian SMEs with foreign markets. The data were analyzed using factor analysis, spearman correlation and regression analysis. The results show that these SMEs offer their customers products tailored to their needs, practice competitive pricing and use distribution networks involving local and communication facilities that were tailored to the requirements of the environment. The researcher concludes that the capacity of SMEs to adjust to the requirements of the environments and to offer products adapted to the customers' needs at competitive prices through a network is essential to their internationalization.

Zhou, Wu, and Luo (2007) carried out a study to examine the mediating role of guanxi-related social networks on the relationship between internationalization and performance. The study adopted survey design and questionnaire technique to collect data from SMEs in the Eastern province of Zhejiang in China. The structural equation model of the analyzed data show some support for the mediating role of social networks in the form of guanxi. The researchers concludes that international business managers should consider social networks as efficient means of helping internally oriented SMEs to go international more rapidly and profitably.

Seerat, Ali, and Arif (2011) conducted a study to investigate the impact of networks on the internationalization patterns and processes of SMEs in Pakistan. The study adopted interview survey for data collection and "pattern-matching" technique for data analysis. It was found that the small firms began operations with the intent to internationalize and this intension was mainly enhanced once the entrepreneurs discuss it with people they trust most in both formal and informal networks. These networks give the active actors access to important advice, more social capital and additional relationships in foreign markets. Seerat and her colleagues conclude that networks impact the internationalization process of small and medium enterprises.

\section{Methodology}

Survey design was adopted for this study. The study employed proportionate stratified random sampling and simple random sampling techniques. Proportionate stratified random sampling technique was used to allocate to the States, family businesses (or founder/CEOs), upper level male managers and upper level female managers strata a representative proportion of the sample size. This was achieved using Bowley (1937) formula. The Table of Random Numbers was used as a simple random sampling technique to select from each of the States the family businesses that were studied. The population of trading, transportation, construction, fashion designing, printing, publishing, manufacturing, production, furniture/wood works, services, and petroleum products marketing businesses that were obtained from the respective States (Abia, Anambra, Ebonyi, Enugu and Imo States) Ministries of Commerce and Industry were screened based on predetermined criteria. The criteria are that: (i) one or more of the founder/CEO's family member work in the business; (ii) 
the business was established between 1970 and 2017; (iii) the business is not moribund; (iv) the business is located in the founder's state of origin or residence; and (v) the business has not less than 5 but not more than 200 staff.

Consequently, the population of the study is 2632. This is made up of 658 family businesses (i.e., number of founder/CEOs), 1749 upper level male managers and 225 upper level female managers. The sample size of 335 was computed from the population using Krejcie and Morgan (1970) formula for finite population. The sample size is made up of 84 family businesses (i.e., number of founders/CEOs), 222 upper level male managers and 29 upper level female managers. The study data were generated using questionnaire. The variables in the questionnaire were measured on a 5-point Likert scale that ranged from strongly agree (5) to strongly disagree (1). The questionnaire was validated by two experts in management. The validity was reconfirmed using Bartlett's Test of Sphericity (1598.794, Sig. = 0.00) and Kaiser-Meyer-Olkin (KMO) measure of sampling adequacy (0.746) which is above 0.70 as recommended by Neuman (2006). The reliability of the questionnaire was confirmed by the overall Cronbach's alpha value of 0.793 .

\subsection{Research Hypothesis}

Social network has significant and positive effect on family business internationalization.

\subsection{Model Specification}

The general model for this study is given as:

$\mathrm{FBI}=f(\mathrm{SNK})$

Where

FBI $=$ family business internationalization

SNK $=$ social network

The general linear regression model is given as:

$\mathrm{Y}=\beta_{0}+\beta_{1} \mathrm{X}+\mathrm{e}$

Where

$\mathrm{Y}=$ estimated value of the dependent variable

$\beta_{0}=$ the intercept of the line with $\mathrm{Y}$ - axis

$\beta_{1}=$ the slope. It estimates the rate of change in $\mathrm{Y}$ for a unit change in $\mathrm{X}$

$\mathrm{X}=$ independent variable

$\mathrm{e}=$ random error

The research hypothesis was tested using the model in equation (iii). Data analysis using the model helped to determine the effect of social network on family business internationalization. The apriori expectation was that social network was expected to positively affect family business internationalization, while absence of social network was expected to negatively affect family business internationalization.

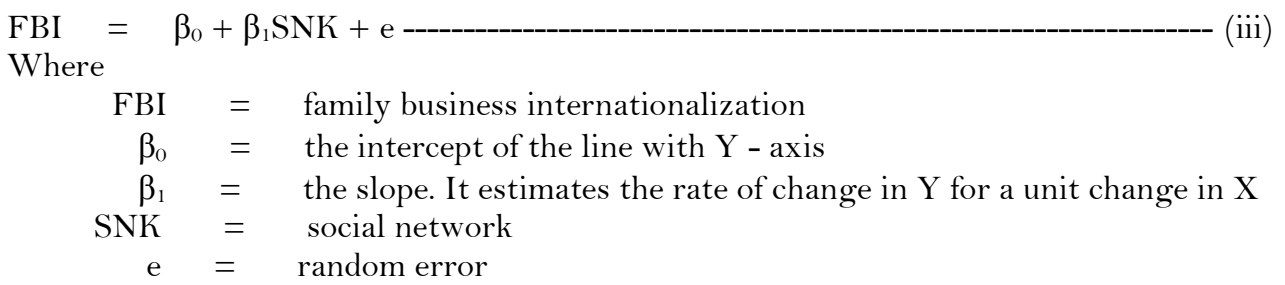

The 335 questionnaire were administered by the researcher with the help of five research assistants. These research assistants were trained specifically for this research. A total of 330 of the questionnaire were retrieved, while only 320 were useable. This implies a response rate of $97.0 \%$. Data on the responses were analyzed using frequency counts and simple percentages, while the research hypothesis was tested using simple regression with the aid of SPSS (Version 21.0 for Windows). The decision rule was to reject the null hypothesis if the p-value is less than or equal to $5 \%$. Otherwise the null hypothesis is not rejected.

\subsection{Test of Hypothesis}

$\mathbf{H}_{\text {o: }}$ Social network has no significant and positive effect on family business internationalization.

$\mathbf{H}_{\mathbf{a}}$ : Social network has significant and positive effect on family business internationalization.

\subsection{Summary of the Analysis of the Coded Responses on the Questionnaire Item Statements}

The summary of the analysis of the coded responses on the questionnaire item statements in Appendix I are presented in Table 1. The analysis was based on a 5-point degree of response (i.e., Strongly Agree $=\mathrm{SA}$, Agree $=\mathrm{A}$, Undecided $=\mathrm{U}$, Disagree $=\mathrm{D}$ and Strongly Disagree $=\mathrm{SD})$. Inferences were drawn from the 
analysis based on a threshold of 3.0 from a possible point of 5.0. This represents the mean of the attached weights to the responses (i.e., $5+4+3+2+1 / 5$ ).

Table-1. Analysis of the Coded Responses on Questionnaire Item Statements 1-4.

\begin{tabular}{|c|c|c|c|c|c|c|c|c|c|c|}
\hline \multirow[t]{2}{*}{ Degree of Response } & \multicolumn{2}{|c|}{ QIS1 } & \multicolumn{2}{|c|}{ QIS2 } & \multicolumn{2}{|c|}{ QIS3 } & \multicolumn{2}{|c|}{ QIS4 } & \multicolumn{2}{|c|}{ Total } \\
\hline & $\mathbf{F}$ & $\%$ & $\mathbf{F}$ & $\%$ & $\mathbf{F}$ & $\%$ & $\mathbf{F}$ & $\%$ & $\mathbf{F}$ & $\%$ \\
\hline SA & 86 & 26.87 & 78 & 24.38 & 109 & 34.06 & 70 & 21.87 & 343 & 26.80 \\
\hline $\mathrm{A}$ & 102 & 31.88 & 115 & 35.94 & 85 & 26.56 & 95 & 29.69 & 397 & 31.02 \\
\hline $\mathrm{U}$ & 33 & 10.31 & 33 & 10.31 & 23 & 7.19 & 5 & 1.56 & 94 & 7.34 \\
\hline $\mathrm{D}$ & 64 & 20.00 & 68 & 21.25 & 78 & 24.38 & 83 & 25.94 & 293 & 22.89 \\
\hline SD & 35 & 10.94 & 26 & 8.12 & 25 & 7.81 & 67 & 20.94 & 153 & 11.95 \\
\hline Total & 320 & 100.0 & 320 & 100.0 & 320 & 100.0 & 320 & 100.0 & 1280 & 100.0 \\
\hline Mean & 3.44 & & 3.47 & & 3.55 & & 3.06 & & 3.38 & \\
\hline $\mathrm{S}$ & 1.66 & & 1.67 & & 1.70 & & 1.58 & & 1.64 & \\
\hline
\end{tabular}

Note: QIS = Questionnaire Item Statement, F = Frequency, SA = Strongly Agree, A = Agree.

$\mathrm{U}=$ Undecided, $\mathrm{D}=$ disagree, $\mathrm{SD}=$ Strongly Disagree, $\mathrm{S}=$ Standard Deviation.

Source: Author's Computation, 2017.

Table 1 revealed that $58.75 \%$ (188) of the respondents affirmed the first questionnaire item statement in Appendix I. The responses show an aggregate mean value of 3.44 which is higher than the threshold of 3.0. Based on this statistics it can be inferred that family business founder/CEOs with similar minds in social association and/or non-governmental organization start cross border business after attaining a high position in the domestic market. The analysis of the responses generated from the second questionnaire item statement show that $60.32 \%$ (193) of the respondents confirmed the statement. The responses further show an aggregate mean value (3.47) that is higher than the threshold of 3.0. It can therefore be deduced from the statistics that the proximity of the founder/CEO to those in the network facilitates linkages to suppliers, customers and human resources across national borders.

The analysis of the responses to the third questionnaire item statement show that $60.62 \%$ (194) of the respondents confirmed the statement. The responses also gave an aggregate mean value of 3.55 which is higher than the threshold of 3.0. The statistics therefore implies that a strong relationship between the founder/CEO and others in the network fosters exposure to international experience and knowledge. Furthermore, the analysis of the responses to the fourth questionnaire item statement shows that $51.56 \%(165)$ of the respondents affirmed the statement. The responses also gave an aggregate mean value (3.06) which is higher than the threshold of 3.0. It can therefore be deduced that founder/CEOs who maintain a strong relationship with members of their network start exporting to nearby countries and later expand to remote countries. Overall, the $57.82 \%$ aggregate affirmation to all the questionnaire item statements and the overall aggregate mean value of 3.38 depicts that social network has effect on family business internationalization.

\subsection{Test of Hypothesis}

$H_{0}$ : Social network has no significant and positive effect on family business internationalization.

$H_{a}$ : Social network has significant and positive effect on family business internationalization.

The results of the goodness-of-fit and the significance of the regression of family business internationalization on social network are presented in Tables 2 (a) and $2(b)$.

Table-2(a). Goodness-of-fit of the Regression of Family Business Internationalization on Social Network.

\begin{tabular}{l|l|l|l|l|l}
\hline Model & R & R Square & Adjusted R Square & Std. Error of the Estimate & Durbin-Watson \\
\hline 1 & .659 & .434 & .415 & .463 & 1.799 \\
\hline
\end{tabular}

Predictors: (Constant), Social network.

Dependent Variable: Family business internationalization.

Source: Author's Computation, 2017.

Table-2(b). Significance of the Regression of Family Business Internationalization on Social Network.

\begin{tabular}{l|l|l|l|l|l|l|l|}
\hline & $\begin{array}{l}\text { Standardized } \\
\text { Coefficients }\end{array}$ & $\begin{array}{l}\text { Standardized } \\
\text { Coefficients }\end{array}$ & & \multicolumn{3}{c}{ Collinearity Statistics } \\
\hline Model & B & Std. Error & Beta & T & Sig. & Tolerance & VIF \\
\hline 1 (Constant) & 5.825 & .639 & & 9.115 & .000 & & .758 \\
\hline Social network & .287 & .054 & .263 & 5.315 & .004 & .75 & 1.072 \\
\hline
\end{tabular}

Dependent Variable: Family business internationalization.

Source: Author's Computation, 2017.

The result of the goodness-of-fit of the regression of family business internationalization on social network in Tables 2 (a) reveals that a strong relationship exists between social network and family business internationalization $(\mathrm{R}=.659)$. Thus, social network influences family business internationalization. The coefficient of determination $\left(\mathrm{R}^{2}\right)$ of .434 reveals that social network facilitates family business 
internationalization. Adjusted $\mathrm{R}^{2}$ reveals that social network explained $41.5 \%\left(\mathrm{Adj} . \mathrm{R}^{2}=.415\right)$ of the total variation in family business internationalization, while the standard error (.463) suggests that social network is significant in explaining the variation in family business internationalization. Thus, social network is important in facilitating family business internationalization. The Durbin-Watson value of 1.799 is approximately 2.000; there is no autocorrelation in the errors of the regression model. Thus, the predictor is somewhat significant. The collinearity statistics in Table 2 (b) reveals a tolerance value of .758 and a VIF value of 1.072. Since the tolerance value is higher than .40 and the VIF value is less than 2.500, it implies that the data has no collinearity problems. Table $2(b)$ further reveals that the effect of social network on family business internationalization is significant and positive $(\beta=.263, \mathrm{t}=5.315, \mathrm{P}<.05)$. We therefore reject $\mathrm{H}_{05}$ and conclude that social network has significant and positive effect on family business internationalization.

\section{Discussion and Conclusion}

The result of this study is consistent with that obtained by Bello (2009), Zhou et al. (2007) and Seerat et al. (2011). Bello found that network facilitates internationalization by enhancing the capacity of SMEs to adjust to the requirements of the environments and to offer products adapted to the customers' needs at competitive prices. Zhou et al. found that international business managers consider social networks as efficient means of helping internally oriented SMEs to go international more rapidly and profitably. Seerat et al. (2011) found that small firms start operations with the intent to internationalize. Over time, this intension is transformed into a network of formal and informal contacts. This network facilitates access to additional relationships and commitments in foreign markets.

Most firms start small and gradually internationalize, while others start as international firms (Chelliah et al., 2010). Basly (2007) argue that family businesses internationalize after developing in their home country. Family businesses achieve internationalization faster when working in collaboration with others. This collaboration can take the form of exploitation of goods/services, shareholding by foreigners, inclusion of foreigners in the top management board and establishment of foreign subsidiaries (Chelliah et al., 2010; da Silva \& de Macedo-Soares, 2013; Pukall \& Calabro, 2014). Firm's intention to venture abroad may be triggered and facilitated by the contacts in its existing network (Johanssons \& Vahlne, 2009; Pukall \& Calabro, 2014). However, the nature of the relationships within the network is the main drivers of firm internationalization (Johanssons \& Vahlne, 2009). Entrepreneurs relate with others in the network through physical contact (in clubs and social gatherings) or through social networking platforms (Ogunnaike \& Kehinde, 2013).

Entrepreneurs maintain this relationship during international expansion than during domestic expansion because of the need for more resources during internationalization (Seerat et al., 2011). Family characteristics that influence internationalization include family members' commitment and believe that the geographical scope of the business is beyond the borders of the country of origin. Others are the education and experience of family members and the level of involvement of the family members in the business either through active participation in the management or through shareholding (Bjornberg \& Nicholson, 2012; Cerrato \& Piva, 2012; Huang et al., 2014; Mazzola et al., 2008; Segaro, 2012). Expansion into international markets can be hampered by lack of strategic resources and inadequate knowledge of the international business environment (Chen, 2011; Gulsoy et al., 2013; Mazzola et al., 2008). In spite of these challenges, internationalization still offer family businesses access to new resources, access to foreign stakeholders (Holt, 2012; Lin, 2012; Machisio et al., 2010), economies of scale and scope, more revenues and opportunity to spread investment risks in different countries (Murray \& Robert, 2013; Shane et al., 2012; Tsao \& Lien, 2013).

The study is not without limitation. The study is limited by the withdrawn information by the questionnaire respondents. This limitation which constitutes a methodological bias is associated with the use of questionnaire. To make-up for the withdrawn information, researchers conducting further studies in this area can employee interview technique or a combination of questionnaire and interview technique. The use of founder/CEOs as single respondents from the families studied is another limitation. The empirical measurement of variables on the basis of the perceptions of founder/CEOs only can be subjective and a source of bias. The bias associated with generating data from only insiders to the family business (i.e., founder/CEOs, upper level male managers and upper level female managers) can be minimized in further studies by including family members, customers and/or suppliers as respondents. The study is also limited to the small and medium sized family businesses in South Eastern Nigeria which has five out of the nation's thirty six states and Abuja. This suggests a narrow demographic scope. Thus, it can limit the generalization of the results. The generalization of the results can be enhanced by conducting a comparative study involving Northern and Southern Nigeria. Similarly, further study can adopt a sample plan that will entail increasing the demographic scope of the study by selecting States from each of the six geopolitical zones in Nigeria.

In spite of these limitations, the outcome of this study lends itself as a veritable empirical evidence and support to the Uppsala Internationalization Process Model. This depicts that networks and network relationships are the main drivers of firm internationalization. To promote cross border business, family business founder/CEOs or descendant/CEOs should be sensitized on the need to belong to both national and international social associations. This social relationship has the potential of: fostering in founder/CEOs the 
use of social networking platforms for communication; exposing the founder/CEOs to international business knowledge/experience; and linking founder/CEOs to foreign partners, investors, funds, facilities and markets.

\section{References}

Abou-Moghli, A., \& Al Muala, A. (2012). Impact of entrepreneurial networks in the success of business on-going stage in Jordanian manufacturing companies. American Academic \& Scholarly Research Journal, 4(2), 1-9.

Aldrich, H., \& Zimmer, C. (1986). Entrepreneurship through social networks. In D. L. Sexton \& R. W. Smilor (Eds.), The art and science of entrepreneurship (pp. 3-23). Cambridge: Ballinger.

Aldrichh, H. E., \& Martinez, M. A. (2001). Many are called but few are chosen: An evolutionary perspective for the study of entrepreneurship. Entrepreneurship Theory \& Practice, 25, 41-57.

Anagbogu, I. (2008). Igbo business in Nigeria. Awka: Sellyoak.

Anderson, A. R., Jack, S. L., \& Dodd, S. D. (2005). The role of family members in entrepreneurial networks: Beyond the boundaries of the family firm. Family Business Review, 18(2), 135-154.

Arthurs, J., Hoskisson, R., Busenitz, L., \& Johnson, R. (2008). Managerial agents watching other agents: Multiple agency conflicts regarding under pricing in IPO firms. Academy of Management Journal, 51, 277-294.

Ayranci, E. (2010). Family involvement in and institutionalization of family business: A research. Business and Economic Horizons, 3(3), 83-104.

Barney, J. (1991). Firm resources and sustained competitive advantage. Journal of Management, 17(1), 99-120.

Barrett, M. (2014). Theories to define and understand family firms. In H. Hasan (Ed.), Being pratical with theory: A window into business research. Wollongong: Theori.

Basly, S. (2007). The internationlization of family SME: An organizational learning and knowledge development perspective. Baltic Journal of Management, 2, 154-180.

Batiz-Lazo, B., \& Woldesenbet, K. (2006). The dynamics of product and process innovation in UK banking. International Journal of Financial Services Management, 1(4), 400-42 1.

Belenzon, S., Patacconi, A., \& Zarutskie, R. (2015). Married to the firm? A large scale investigation of the social context of ownership. Paper presented at the Paper Presented at Duke University.

Bello, P. (2009). Internationalization of Cameroonian small and middle enterprises (SMEs): Myth or reality? African Journal of Business Management, 3(2), 052-069.

Bjornberg, A., \& Nicholson, N. (2012). Emotional ownership: The next generation's relationship with family firm. Family Business Review, 25(4), 374-390.

Bowley, A. L. (1937). Elements of statistics. London: P. S. Kings and Staples.

Brutton, G., Filatotchev, L., Chahine, S., \& Wright, M. (2010). Governance, ownership structure and performance of IPO firms: The impact of different types of private equity investors and institutional environments. Strategic Management Journal, 31, 491-509.

Cerrato, D., \& Piva, M. (2012). The internationalization of small and medium-sized enterprises: The effect of family management, human capital and foreign ownership. Journal of Management and Governance, 16(4), 61 7-644.

Chell, E., \& Baines, S. (2000). Networking, entrepreneurship and micro-business behaviour. Entrepreneurship $\Theta^{2}$ Regional Development, 12, 195-215.

Chelliah, S., Pandian, S., Sulaiman, M., \& Munusamy, J. (2010). The moderating effect of firm size: Internationalization of small and medium enterprises (SMEs) in the manufacturing sector. African Journal of Business Management, 4(14), 3096-3109.

Chen, H. L. (201 1). Internationalization in Taiwanese family firms. Global Journal of Business Research, 5(4), 15-23.

Chuairuang, S. (2013). Relational networks and family firm capital structure in Thailand: Theory and practice. (Unpublished Ph.D Thesis). Mea University, Mea, Sweden.

Coutinho, R. J. F., \& Moutinho, R. M. (2012). Generational succession as a trigger for family business internationalization. Economics and Management Research Projects, 2(1), 1-17.

da Silva, G. F., \& de Macedo-Soares, T. D. (2013). The role of international alliance networks and their impact on firms' internationalization process. Bento Gonzalves, 19(21), 1-16.

Duran-Encalada, J. A., Martin-Reyna, J. M. S., \& Montiel-Campos, H. (2012). A research proposal to examine entrepreneurship in family business. Journal of Entrepreneurship, Management and Innovation, 8(3), 58-77.

Elfring, T., \& Hulsink, W. (2003). Networks in entrepreneurship: The case of high-technology firms. Small Business Economics, 21(4), 409-422.

Ferreira, J. J., Azevedo, S. G., \& Ortiz, R. F. (2011). Contribution of resource-based view and entrepreneurial orientation on small firm growth. Cuadernos De Gestion, 11(1), 95-116.

Fombrun, C. J. (1982). Strategies for network research in organizations. Academy of Management Reviere, 7(2), $280-291$.

Gersick, K. E., Davis, J. A., McCollom, M., Hampton, M., \& Lansberg, I. (2007). Generation to generation - life cycles of the family business. Boston: Harvard Bsuiness School Press.

Granovetter, M. (1973). The strength of weak ties. American Journal of Sociology, 78, 1360-1380.

Granovetter, M. (1983). The strength of weak ties: A network theory revisited. Sociological Theory, 1, 201-233.

Gulsoy, T., Ozkanly, O., \& Lynch, R. (2013). Effective international expansion strategies of emerging countries: The strategies that helped Arcelik. Management Research Revierw, 36(1), 4-32.

Hamid, N. F. B. A. (2013). Family business culture, entrepreneurial orientation and the new economic policy on family business survival: A study between the Malays and Chinese of micro and small-sized family business in Malaysia. (Unpublished Ph.D Thesis) The University of York, York.

Harris, L., \& Rae, A. (2009). The revenge of the gifted amateur: Be afraid, be very afraid. Journal of Small Business and Enterprise Development, 16(4), 694-709.

Holt, D. T. (2012). Strategic decisions with family firms: Understanding the controlling family's receptivity to internationlization. Entrepreneurship Theory E Practice, 36(6), 1145-1 151. 
Huang, K., Lo, S. C., Liu, C., \& Tung, J. (2014). Internationalization of family business: The effect of ownership and generation involvement. Anthropologist, 17(3), 757-767.

Ichraikie, F. (2013). Intangible resources as key determinants of job network providers' success: A resource-based study. Australian Journal of Business and Management Research, 2(11), 43-63.

Jensen, M. C., \& Meckling, W. H. (1976). Theory of the firm: Managerial behaviour, agency costs, and economic organization. Journal of Financial Economics, 3(4), 305-360.

Johannission, B., Ramirez-Pasilas, M., \& Karlson, G. (2002). The institution embeddedness of local inter firm networks: A leverage for business creation. Entrepreneurship \& Regional Development, 14, 297-315.

Johansson, J., \& Vahlne, J. (1977). The internationalisation process of the firm: managerial behaviour, agency costs, and ownership structure. Journal of International Business Studies, 8(1), 23-32.

Johanssons, J., \& Vahlne, J. E. (2009). The Uppsala internationalization process model revisited: From liability of foreignness to liability of outsidership. Journal of International Business Studies, 40, 1411-1431.

Kaplan, A. M., \& Haenlein, M. (2010). Users of the world unite! The challenges and opportunities of social media. Business Horizons, 53, 59-68.

Kozan, M. K., \& Akdeniz, L. (2014). Role of strong versus weak networks in small business growth in an emerging economy. Administrative Sciences, 4(1), 35-50. Available at: 10.3390/admsci40 10035.

Krejcie, R. V., \& Morgan, D. W. (1970). Determining sample size for research activities. Educational and Psychological Measurement(30), 607-610.

Lechner, C., Dowling, M., \& Welpe, I. (2006). Firm networks and firm development: The role of the relational mix. Journal of Business Venturing, 21, $514-540$.

Lin, W. T. (2012). Family ownership and internationalization process: Internationalization pace, internationalization scope, and internationalization rhythm. European Management Journal, 30(1), 47-56.

Machisio, G., Mazzola, P., Sciascia, S., Miles, M., \& Astrachan, J. (2010). Corporate venturing in family business: The effects on the family and its members. Entrepreneurship and Regional Development, 22(3/4), 349-377.

Masum, M. I., \& Fernandez, A. (2008). Internationalization process of SMEs: Strategies and methods. School of Sustainable Development of Society and Technology. Vasteras, Sweden.

Mazzola, P., Machisio, G., \& Astrachan, J. (2008). Strategic planning in family business: A powerful developmental tool for the next generation. Family Business Review, 21(3), 239-258.

Murray, T., \& Robert, J. (2013). Understanding the pace, scale and pattern of firm internationalization: An extension of the "born global" concept. International Small Business Journal, 31(6), 701-721.

Naldi, L., \& Nordqvist, M. (2008). Family firms venturing into international markets: A resource dependence perspective. Jonkoping International Business School, Jonkoping, Sweden.

Neergaard, H. (2005). Networking activities in technology-based entrepreneurial teams. International Small Business Management, 23(3), 257-278.

Neuman, L. (2006). Social research methods: Qualitative and quantitative approaches. London: Pearson International.

Ogunnaike, O. O., \& Kehinde, O. J. (2013). Social networking and business performance: The case of selected entrepreneurs in Ota, Nigeria. Journal of Business and Management Sciences Research, 2(5), 116-122.

Palanissamy, A. (2014). Investor relations - integrating social media into board - Oman perspective. European Journal of Business and Management, 6(24), 108-113.

Patel, V. K., Pieper, T. M., \& Hair, J. F. (2012). The global family business: Challenges and drivers for cross-border growth. Business Horizons, 55(3), 231-239.

Pfeffer, J., \& Salancik, G. R. (1978). The external control of organizations: A resource dependence perspective. New York: Harper and Row.

Poza, D. (2014). Family business. New York: South-Western: Cengage Learning.

Pukall, T. J., \& Calabro, A. (2014). The internationalization of family firms: Critical review and integrative model. Family Business Review, 27(2), 103-125. Available at: 10.1177/0894486513491423.

Ramona, K. Z., Hoy, F., Poutziouris, P. Z., \& Steier, L. P. (2008). Emerging paths of family entrepreneurship research. Journal of Small Business Management, 46(3), 317-330.

Salancik, G. R., \& Pfeffer, J. (1978). A social information processing approach to job attitudes and task design. Administrative science quarterly, 224-253.

Schjoedt, L., Monsen, E., Pearson, A., Barnett, T., \& Chrisman, J. J. (2012). New venture and family business teams: Understanding team formation, composition, behaviours and performance. Entrepreneurship Theory and Practice, $37(1), 1-15$.

Seerat, F., Ali, M., \& Arif, S. (2011). Network classification on the basic of functions they perform and its relationship with internationalization process of SMEs in developing countries - Exploratory research on Pakistan. Australian Journal of Business and Management Research, 1(8), 35-53.

Segaro, E. (2012). Internationalization of family SMEs: The impact of ownership, governance and top management team. Journal of Management and Governance, 16(1), 147-169.

Sengenberger, W., \& Pyke, F. (1992). Small firm industrial districts and local economic regeneration. Retrieved from http://econpapers.repec.org/paper/iloilowps/277922.htm.

Shane, M., Marilyn, H., \& Rumintha, W. (2012). The internationalization of information, knowledge and interaction components of the firm's internationalization process. Journal of Marketing Management, 28(5/6), 733-754.

Sheriff, R. E. (2012). An evaluation of students' and lectures' use of technologies: An engineering case study. Engineering Education, 7(1), 33-46.

Smelser, N. J., \& Baltes, P. B. (2001). International encyclopedia of the social and behavioral science. Exeter: Cambridge University Press. 
Surin, E. F., \& Wahab, I. A. (2013). The effect of social networks on business performance in established manufacturing small and medium enterprises (SMEs) in Malaysia. International Proceedings of Economic Development and Research, 67(12), 55-59. Available at: 10.7763/IPEDR.

Tsao, S. M., \& Lien, W. H. (2013). Family management and internationalization: The impact on firm performance and innovation. Management International Review, 53(2), 189-213.

Warnar, P. (2012). Family business and knowledge transfer: How to survive to the next generation. Delft University of Technology.

Welsh, D. H. B., Memili, E., Rosplock, K., Roure, J., \& Segurado, J. L. (2013). Perceptions of entrepreneurship across generations in family offices: A stewardship theory perspective. Journal of Family Business Strategy, 4(3), $213-226$.

Wernerfelt, B. (1984). A resource-based view of the firm. Strategic Management Journal, 5(2), $171-180$.

Westhead, P., Wright, M., \& McElwee, G. (2011). Entrepreneurship perspectives and cases. London: Pearson Education.

Zahra, S. A., Hayton, J. C., \& Salvato, C. (2012). Entrepreneurship in family vs. non-family firms: A resource-based analysis of the effect of organizational culture. Entrepreneurship Theory Eं Practice, 28(4), 363-381.

Zhou, L., Wu, W., \& Luo, X. (2007). Internationalization and the performance of born-global SMEs: The mediating role of social networks. Journal of International Business Studies, 38(4), 673-690. Available at: 10.1057 /palgrave.jibs.8400282.

\section{Appendix 1}

S/N Item Statement
Effect of Social Network on Family Business Internationalization

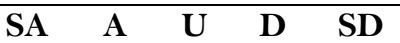

1. Founder/CEOs with similar minds in social association and/or non-governmental organization start cross border business after attaining a high position in the domestic market.

2. The proximity of the founder/CEO to those in the network facilitates linkages to suppliers, customers and human resources across national borders.

3. A strong relationship between the founder/CEO and others in the network fosters exposure to international experience and knowledge.

4. Founder/CEOs who maintain a strong relationship with members of their network start exporting to nearby countries and later expand to remote countries. 